\title{
An Investigation of Instructors' Approaches in Teaching Pronunciation: A Case Study
}

\author{
Bakheit Mohamed Abdelgadir Elnagar ${ }^{1}$ \\ ${ }^{1}$ King Abdulaziz University, Jeddah, Saudi Arabia \\ Correspondence: Bakheit Mohamed Abdelgadir Elnagar, King Abdulaziz University, Jeddah, Saudi Arabia
}

Received: July 4, 2020

Accepted: July 26, 2020

Online Published: July 30, 2020

doi: $10.5539 /$ elt.v13n8p185

URL: https://doi.org/10.5539/elt.v13n8p185

\begin{abstract}
This study aimed to investigate how instructors teach pronunciation based on the pronunciation training they received. This study involved instructors from King Abdul Aziz University, who were teaching at the English Language Institute (ELI). The data were collected through a questionnaire given to (50) instructors at (ELI). The data were analyzed using Statistical Package for the Social Sciences (SPSS) program.

The results displayed that instructors used cognitive-content of teaching pronunciation and most of them focused on it as a valuable teaching approach. Furthermore, the findings revealed that the instructors had a constructive trend in teaching pronunciation. Most instructors pointed out that they taught pronunciation in their classes; in many cases they spent a considerable amount of time in pronunciation instruction. The lack of the pronunciation equipment and technological resources stands as a stumbling- block problem to teaching this language skill. In addition, the findings showed most of the language instructors did not receive any specific pronunciation training. Recommendations are given to provide suitable teaching pronunciation training which prepares the instructors to use powerful technology to boost teaching of this essential skill.
\end{abstract}

Keywords: EFL instructors, teacher training, pronunciation, English language techniques

\section{Introduction}

Teaching pronunciation is a controversial topic (Foote et al., 2016). The discussions on this issue are highlighted in the role of explicit pronunciation and the effective approaches to teaching pronunciation (Saito, 2011).

In the language teaching environment, there are two eminent stakeholders: the student and the instructor. The present study focuses on the latter. Borg (2003) articulates that "instructors are active, thinking decision- makers who make instructional choices by drawing on complex, practically-oriented, personalized, and context-sensitive networks of knowledge, thoughts, and beliefs" (p. 81). Most of the studies implemented in the area of teaching pronunciation concentrated on the analysis of pronunciation errors produced by Saudi learners (e.g., Ahmad \& Muhiburrahman, 2013; Bintuki, 2008) and pronunciation difficulties and problems faced by students (Hameed \& Aslam, 2015). Hence, this study aims to investigate ELI instructors' approaches on teaching pronunciation as well as to fill the gap in the present literature.

The main research questions that guided the study are as follows:

1-What pronunciation techniques do EFL instructors use at (ELI)?

2-What pronunciation training do EFL instructors have at (ELI)?

In brief, this study aimed to investigate the level of pronunciation training the instructors had and the training opportunities available to them. The findings will provide empirical evidence about the status of pronunciation teaching in English language classes. Thus, the present study may raise EFL instructors' awareness of the significance of teaching pronunciation.

\section{Literature Review}

Teaching English as a foreign language (EFL) requires instructors to concentrate on all language skills. Nevertheless, teaching English pronunciation is still ignored in EFL classrooms (Burns, 2006; Derwing \& Munro, 2005; Foote et al., 2016). MacDonald (2002) argues that this negligence toward pronunciation teaching results from that pronunciation disintegrates simply with foreign language skills, for instance, reading or writing. 
Furthermore, many researchers are convinced that many factors such as the effect of the first language, the age of the learners, and aptitude play various roles with pronunciation than with other skills (Foote et al., 2016).

Hismanoglu (2010) finds that teachers, in general, like to use both classical and authentic pronunciation approaches in their teaching practices. These approaches can be reinforced by doing further studying and training.

Since pronunciation is an essential element to successful communication, reciprocal intelligibility becomes the dominant interest for foreign language learners (Derwing \& Munro, 2005). Therefore, the objective of pronunciation instruction is to approach intelligibility and to activate learners' communicative competence. According to Goodwin (2001), the aim on pronunciation teaching has three dimensions: to enable students to understand and be understood, to construct their trust when joined in the communicative status, and to boost them to observe their speech based on input from the surroundings. Based on Derwing and Munro (2005), ESL and EFL learners' speech is subject to three various viewpoints: intelligibility, accentedness, and comprehensibility. As stated by them, intelligibility refers to "the extent to which the speaker's intended utterance is understood by a listener" (p.385).

Accentedness expresses "how much a second language (L2) accent differs from the variety of English commonly spoken in the community" (p.385), and comprehensibility is "the listener's perception of the degree of difficulty encountered when trying to understand an utterance" (p. 385).

Furthermore, Morley (1991: 263) states "the question is not whether pronunciation should be taught but what should be taught in a pronunciation type and how it should be taught". According to Derwing and Munro (2005) and Derwing, Munro and Wiebe (1998), instructors tend to depend on their own decisions to decide on the emphasis of pronunciation instruction with little direction. Accordingly, Tergujeff (2012a) conducted a study to explore the approaches and pivot areas of teaching English pronunciation in Finnish schools. She used classroom observations for four EFL instructors. The findings revealed that a range of ten various kinds of teaching approaches pronunciation was used, comprising traditional imitation tasks, instructor corrections, instructors' mention of pronunciation issues, use of phonemic script and rhymes, spelling or dictation, reading aloud, presenting rules, sound discernment, and tangible reinforcement. As a result, the four instructors taught pronunciation very variously from each other. Besides, the instructors focused mainly on the sounds that were found to be tough for Finnish learners. Hismanoglu (2010) showed that "language teachers prefer employing traditional classroom techniques, such as dictation, reading aloud, and dialogues to a great extent to teach pronunciation to their students. However, they are reluctant to use modern techniques, such as computers, instructional software, and the internet" (p. 988).

Recently, several researchers have explored the efficacy of explicit pronunciation instruction on learners' development (e.g. Couper, 2003, 2006; Ghorbani, Neissari, \& Kargozari, 2016; Saito, 2007, 2011, 2012). They agree that clear instruction of pronunciation is essential in language classrooms. Ghorbani et al. (2016) said:

\section{Explicit pronunciation in English language teaching engages learners in activities that help them to focus their attention primarily on pronunciation. Explicit teaching takes place when there is no distraction of the mind on other parts of language teaching, such as grammar. However, implicit pronunciation teaching occurs when the mind is concentrated elsewhere. (p. 9)}

In the study of Couper (2003), the aim was to explore the role of teaching pronunciation explicitly rather than implicitly through exposure to the target language. The researcher examined the value of integrating a pronunciation sub-syllabus within the overall syllabus course. The effectiveness of the syllabus was examined through pre-test and post-test of pronunciation. Moreover, the learners were surveyed to gauge their beliefs regarding explicit pronunciation instruction. The findings showed a considerable improvement in accuracy in learners' pronunciation. Besides, a noticeable decrease was found in the phonological errors produced by the learners during the course. Regarding their beliefs, the survey results demonstrated that an explicit pronunciation teaching was valued. In another study, Couper (2006) investigated the impact of obvious instruction on specific pronunciation features. He focused on epenthesis and absence. After attaining a chain of succinct lessons for two weeks, he concluded that the learners showed improvement on both the immediate and the latter post-test. Thus, this specific kind of teaching was effective. He indicated that focused instruction on some features of pronunciation could make changes in learners' phonological interlanguage. As Derwing and Munro (2005) claim that "students learning L2 pronunciation benefit from being explicitly taught phonological form to help them notice the difference between their own productions and those of proficient speakers in the L2 community" (p. $388)$. 
Positive effects of explicit teaching of pronunciation are also reported by Ghorbani et al. (2016). They enabled EFL learners to identify and notice their specific pronunciation errors and then the learners investigated the impact of explicit pronunciation instruction on their vowel perception. The findings revealed that explicit vowel instruction through raising learners' awareness or consciousness was more effective than the implicit teaching of vowels. They contended that formal explicit instruction of the second language phonology should not be underestimated. Similarly, Saito (2007) focused on the effect of explicit pronunciation to improve Japanese learners' pronunciation of the vowel /æ/. He found that the pronunciation of this vowel was improved significantly for the experimental group, while the control group showed disimprovement. Consequently, explicit pronunciation instruction had led the decrease the phonological errors. In a later study, Saito (2011) investigated the part of clear phonetic consideration as an independent variable on two features of second language pronunciation improvement: comprehensibility and recognized accentedness. He conducted a quasi-experimental study with twenty Japanese EFL students. The results pointed out frank instruction positively affected comprehensibility, particularly in the sentence-reading task.

The two types of pronunciation features that are usually discussed in the literature of several studies about pronunciation teaching are: segmental and suprasegmental (Pennington \& Richards, 1986; Setter \& Jenkins, 2005). Segmental features are "minimal units of sound defined in phonetic term" (Pennington \& Richards, 1986, p. 208). Suprasegmental features refer to the characteristics that plan streams of speech into meaningful units such as intonation, rhythm, and stress. Derwing et al. (1998) claim "attention to segmental concerns benefits ESL student. A student who has received segmental training might be able to focus on the mispronounced form in a self-repetition". (p. 407). According to Setter and Jenkins (2005), instructors tended to teach segmental features due to their teachability. In other words, segmental features are more teachable than suprasegmental features. For this reason, pronunciation instruction has traditionally emphasized on segmental features (Jenkins, 2004).

Both foreign language instructors and curriculum designers should beware of the teaching processes of pronunciation. Moreover, teachers' psychological and social characteristics should be incorporated. Effective techniques, enjoyable situations, and learners' needs should be regarded as well (Skorvagova et al., 2017).

However, in recent years, the focus of teaching pronunciation has moved from segmental features to suprasegmental features (Derwing \& Rossiter, 2003; Pennington \& Richards, 1986). Many researchers agree that factors as stress, intonation, and rhythm have more significance in accomplishing reasonable pronunciation. In Derwing et al. (1998), it was found that the students with suprasegmental instruction claimed a considerable improvement in both comprehensibility and fluency. Thus, suprasegmental instruction had a significant influence on speakers when transferring their learning to a spontaneous speech. Several factors can affect learning English pronunciation. First, the influence of the first language - mother tongue - plays a major role in pronunciation (Pennington \& Richards, 1986). For instance, Ahmed (2011) observed that Arab learners of English have some English consonant sounds' pronunciation problems. These particular consonant sounds include $/ \mathrm{p} /, / \mathrm{d} /, / \mathrm{v} /$ and $/ \mathrm{t} /$. He conducted a study to investigate the challenges that Saudi learners faced when uttering these consonant sounds. In the study, eight learners were randomly chosen from Najran University. The results of the study indicated that when Saudi learners speak English language, they are inclined to articulate the sounds that are similar to the sounds found in their first language, which causes pronunciation errors. Al Mafalees (2020) study explained that specific English consonant sounds are hard to pronounce for Yemeni secondary school students. These consonants $(/ \mathrm{p} /-/ \mathrm{b} /, / \mathrm{f} / / / \mathrm{v} /, / \mathrm{t} / /-/ \mathrm{d} z /-/ \mathrm{J} /)$ appear to be difficlut for Yemeni students. Similarly, Hago and Khan's (2015) study showed that Saudi EFL learners have the tendency to split up of consonant clusters by introducing a vowel sound in English syllable. The findings suggested that the interference from the first language is the main factor contributing to pronunciation problems. Therefore, the difference between first language and second language can affect the teaching of pronunciation.

Zoghbor (2018) emphasizes that Arab trainees need to be involved in multiplicity of pronunciation models. They should have such kind of practice to help them to know the closeness between English and Arabic phonological systems.

The second factor that may affect the learners' pronunciation is their age. A number of studies have stressed the common notion that children are superior to adults in terms of acquiring a foreign language (Jones, 1997). Accordingly, children can benefit more than adults from teaching pronunciation. However, Jones (1997) argues that these studies disappoint to ascertain that it is unattainable for learners to attain native-like pronunciation. Adult learners can achieve reasonable improvement in pronunciation skills if they are well motivated and instructed. The other factor is the attitude. Some students are more skilled in improving and acquiring good pronunciation. Elliot (1995) found that if students are more attentive about their target language pronunciation, 
they have a propensity to perfect target sound pronunciation. Gilakjani (2012) adds student's inducement for learning the foreign language and the cultural set that the student points out and employs period limitation regardless the student develops native-like pronunciation. The success in acquiring native-like pronunciation relies on learners' reasons and needs for learning a foreign language and the utilizations they organize to put the language in. For example, learners who need to learn English for better jobs, they are learners who expect to have an immense amount of interaction with native speakers in business, or professional contexts will have various needs and anticipations than learners who arrange to practice the language fundamentally for communication with other non-native speakers (Jones, 1997).

The use of cell phone software and holograms in teaching pronunciation elements is effective and promotes interaction and motivation among EFL learners. According to Cerezo, et al. (2019), those who used authentic applications practice better than those who used old-fashioned techniques.

\section{Methodology}

To answer the two questions mentioned earlier, this study aims to collect as much relevant data as possible. Thus, this study adopted a quantitative research method. The researcher thinks that this questionnaire is suitable and appropriate for this study, which could be viewed as an attempt to investigate instructors' approaches to teaching pronunciation. The questionnaire was adapted from the one used by Foote et al. (2011). The first section asked instructors for background information. Moreover, it included a Likert scale question about pronunciation training. The second section asked instructors for teaching pronunciation resources available to them in the language institute to teach pronunciation. The questions in this section were five-point Likert scale questions. The third section asked about how pronunciation teaching was conducted into general EFL classes. It focused on instructors' practices including the nature and the amount of pronunciation instruction given. Most of the questions in this section were in multiple-choice format. The first section asked instructors for personal background information (such as age, qualification, teaching experience) in a multiple-choice format. The participants were chosen randomly from the total population of the instructors of (ELI) which is about (250) males and females. The researcher involved about thirty instructors which included (25) males and (25) females who responded to the questionnaire statements most of them $(50 \%)$ held a master's in TEFL or applied linguistics.

\section{Data Analysis}

The Statistical Package for Social Sciences (SPSS) version (24) is a statistical software that has been used to conduct the statistical analysis. The researcher used the following statistical techniques:

\subsection{Cronbach's Alpha Coefficient to Test Reliability}

\subsection{Pearson Correlation to Examine Internal Consistency}

4.3 Descriptive Analysis (Frequency and Percentage) to Describe the Respondents and Their Opinions toward Each Statement/Phrase

\subsection{Chi-Square Test for Goodness of Fitness to Test the Perception of the Respondents toward Each} Statement/Phrase

4.5 Some Graphs will be Drawn by Using (Microsoft Excel)

\subsection{Reliability Test}

Table 1. Reliability test by Cronbach's Alpha

\begin{tabular}{cc}
\hline No. of Items & Cronbach's Alpha \\
\hline 10 & 0.885
\end{tabular}

The previous table shows the reliability test by Cronbach's Alpha Test that is $(0.885)$ for the questionnaire with 10 items (phrases). It is a high value ( $>0.70)$, and it indicates that the study tool (questionnaire) is valid and reliable for collecting data. Furthermore, if the questionnaire is re-distributed to the same sample after some time, we will get roughly the same results amounting to $(88.5 \%)$.

\subsection{Internal Consistency}

The internal consistency was calculated for the questionnaire by using the Correlation Coefficient between each statement/phrase and the total score of the questionnaire, and the following table shows the results: 
Table 2. Internal Consistency by Pearson correlation

\begin{tabular}{cccc}
\hline $\begin{array}{c}\text { Item } \\
\text { No }\end{array}$ & $\begin{array}{c}\text { Pearson Correlation } \\
\text { Coefficient }\end{array}$ & Item No & $\begin{array}{c}\text { Pearson Correlation } \\
\text { Coefficient }\end{array}$ \\
\hline 1 & $0.774^{* *}$ & 6 & $0.827^{* *}$ \\
2 & $0.749^{* *}$ & 7 & $0.864^{* *}$ \\
3 & $0.798^{* *}$ & 8 & $0.631^{* *}$ \\
4 & $0.814^{* *}$ & 9 & $0.711^{* *}$ \\
5 & $0.609^{* *}$ & 10 & $0.561^{* *}$ \\
\hline
\end{tabular}

** Correlation is significant at the level (0.01)

From the previous table, we find that all the correlation coefficients range from $(0.561-0.864)$ are high, positive and significant at the level of significance (0.01), which indicate high internal consistency between each statement/phrase and the questionnaire.

\subsection{Descriptive Analysis of the Demographic Characteristics}

Table 3. Frequency distribution of demographic characteristics

\begin{tabular}{lc}
\hline \multicolumn{1}{c}{ Variables } & Result \\
\hline Gender & $26(56.5 \%)$ \\
Female & $20(43.5 \%)$ \\
Male & \\
Qualification & $10(21.7 \%)$ \\
BA & $1(2.2 \%)$ \\
Post graduate diploma & $3(6.5 \%)$ \\
CELTA & $23(50.0 \%)$ \\
MA & $9(19.6 \%)$ \\
PhD & \\
Years of Experience & $8(17.4 \%)$ \\
$0-5$ years & $11(23.9 \%)$ \\
6-10 years & $11(23.9 \%)$ \\
11-15 years & $12(26.1 \%)$ \\
16-20 years & $4(8.7 \%)$ \\
Total and above & $46(100.0 \%)$ \\
\hline
\end{tabular}

Table 3. illustrates the frequency distribution of the sample according to demographic characteristics; it shows the following: Regarding Gender, it was found that $26(56.5 \%)$ of the sample are male instructors, while the rest $20(43.5 \%)$ are female instructors. The following pie-chart illustrates the percentages.

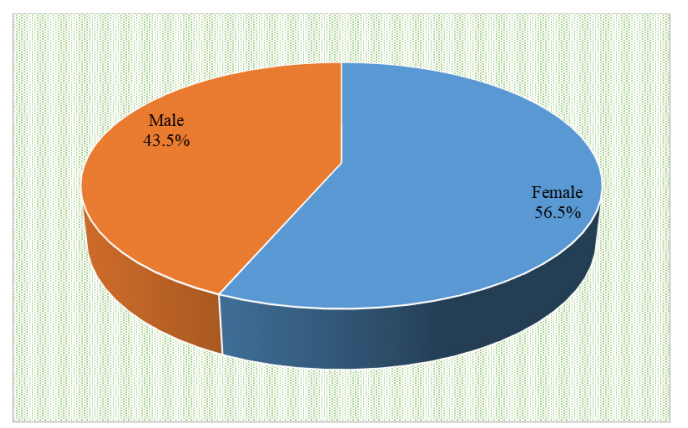

Figure 1. Frequency distribution of the sample according to Gender 
Regarding qualification, we found the 23(50.0\%) of the sample have MA (Master of Art), $10(21.7 \%$ ) have BA (Bachelor of Art), 9(19.6\%) have $\mathrm{PhD}, 3(6.5 \%)$ have CELTA and only one has postgraduate diploma. The following pie chart illustrates these percentages.

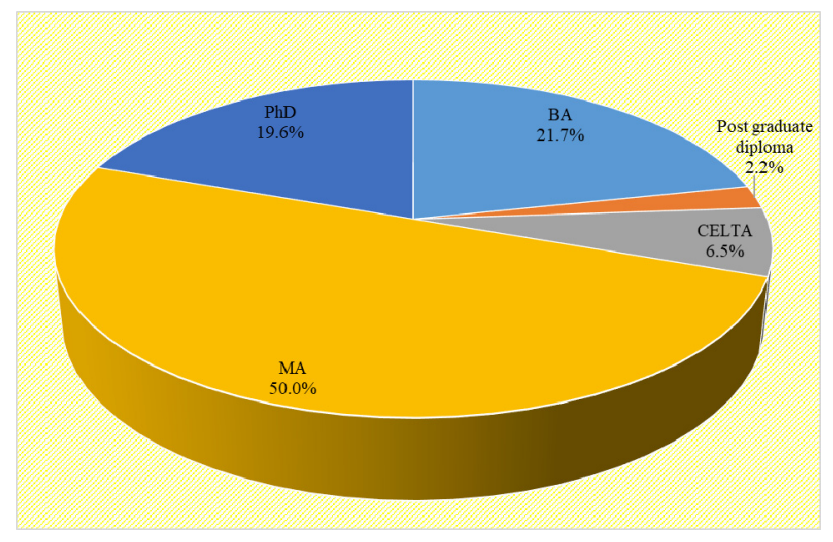

Figure 2. Frequency distribution of the sample according to Qualification

Regarding years of experience, we found that 12(26.1) their years of experience range from (16-20), 11(23.9\%) their years of experience range from (6-10), also $11(23.9 \%)$ range from (11-15) years, and $8(17.4 \%)$ range from (0-5) years, and only $4(8.7 \%)$ have years of experience ( 21 and above). The following bar-chart illustrates these percentages.

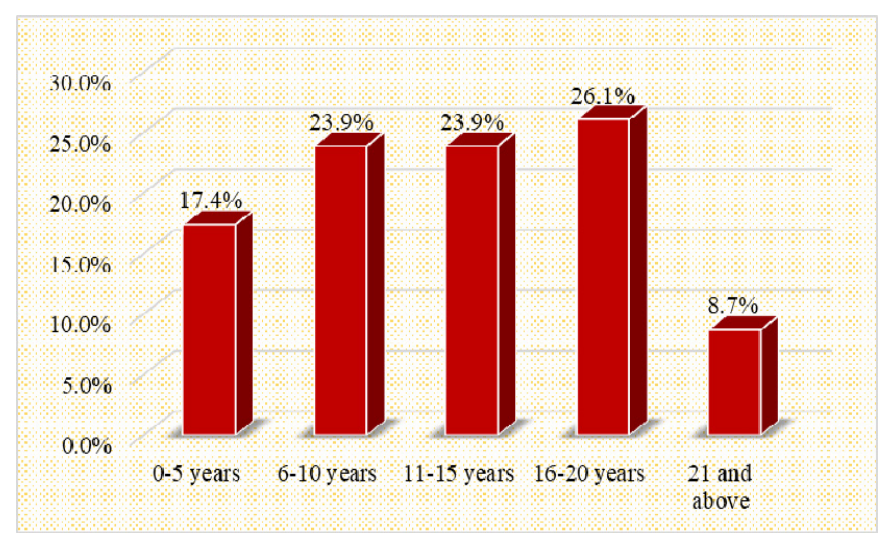

Figure 3. Frequency distribution of the sample according to years of experience

4.9 Descriptive Analysis of Each Statement in the Questionnaire

Table 4. Frequency distribution of the answers to the statement question 1. I studied several courses in teaching pronunciation

\begin{tabular}{|c|c|c|}
\hline Answer & Frequency & Percent \\
\hline Always & 17 & $37.0 \%$ \\
\hline Sometimes & 14 & $30.4 \%$ \\
\hline Never & 15 & $32.6 \%$ \\
\hline Total & 46 & $100.0 \%$ \\
\hline
\end{tabular}

Table 4. shows that 17(37.0\%) of the sample stated that they "always" studied several courses in teaching pronunciation, $15(32.6 \%)$ their response to the statement is "never", while 14(30.4\%) their response is "sometimes". The pie chart below illustrates these percentages. 


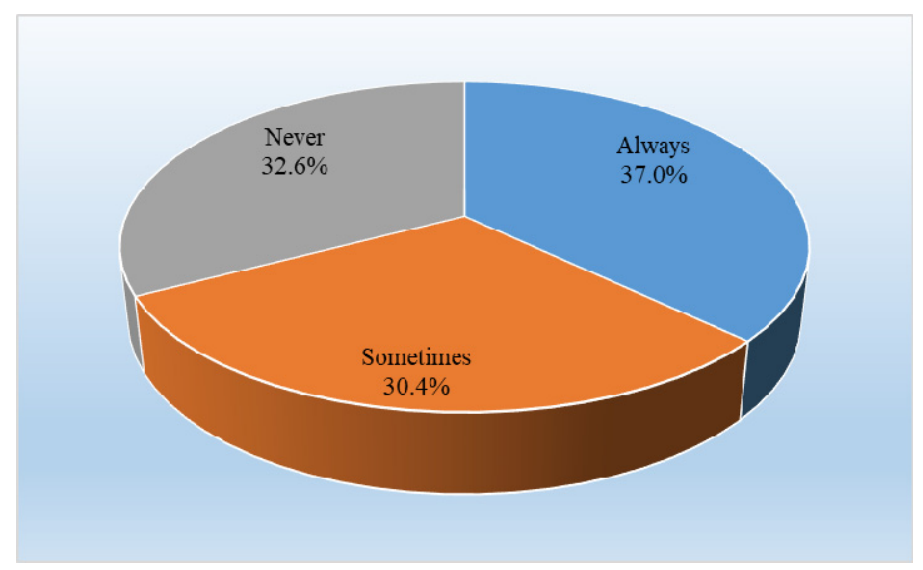

Figure 4. Frequency distribution of question 1. I studied several courses in teaching pronunciation

Table 5. Frequency distribution of the answers to the statement question 2. I have special training on teaching pronunciation

\begin{tabular}{|c|c|c|}
\hline Answer & Frequency & Percent \\
\hline Always & 21 & $45.7 \%$ \\
\hline Sometimes & 19 & $41.3 \%$ \\
\hline Never & 6 & $13.0 \%$ \\
\hline Total & 46 & $100.0 \%$ \\
\hline
\end{tabular}

Table 5. shows that 21(45.7\%) of the sample stated that they "always" (have special training on teaching pronunciation), 19(41.3\%) sometimes have, while only 6(13.0\%) "never" have special training on teaching pronunciation. The pie chart below illustrates these percentages.

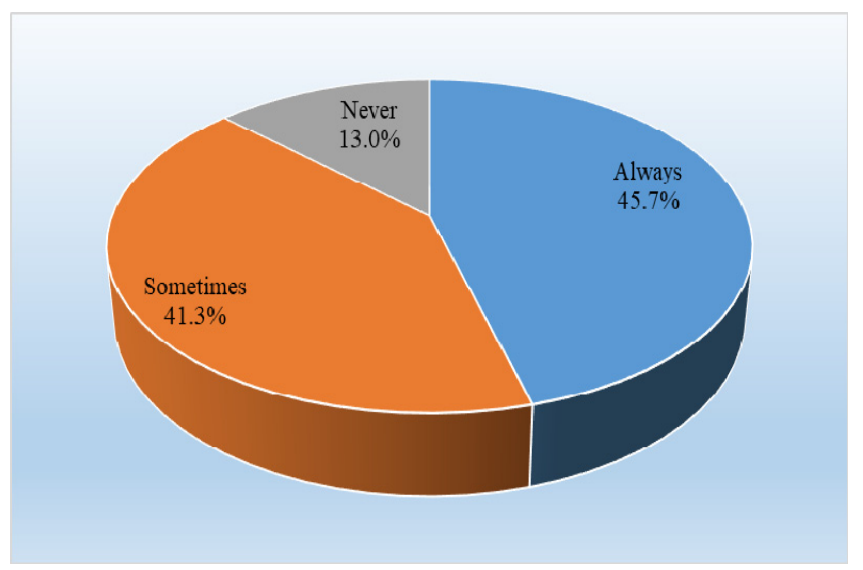

Figure 5. Frequency distribution of question 2. I have special training on teaching pronunciation

Table 6. Frequency distribution of the answers to the statement question 3. I make use of dictionaries as a technique for teaching pronunciation

\begin{tabular}{lcc}
\hline \multicolumn{1}{c}{ Answer } & Frequency & Percent \\
\hline Always & 24 & $52.2 \%$ \\
Sometimes & 16 & $34.8 \%$ \\
Never & 6 & $13.0 \%$ \\
Total & 46 & $100.0 \%$
\end{tabular}

Table 6. shows that more than half 24(52.2\%) of ELI instructors "always" (question 3.), 16(34.8\%) sometimes do that, while only $6(13.0 \%)$ of the respondents "never" answer (question 3.). The bar chart below illustrates these percentages. 


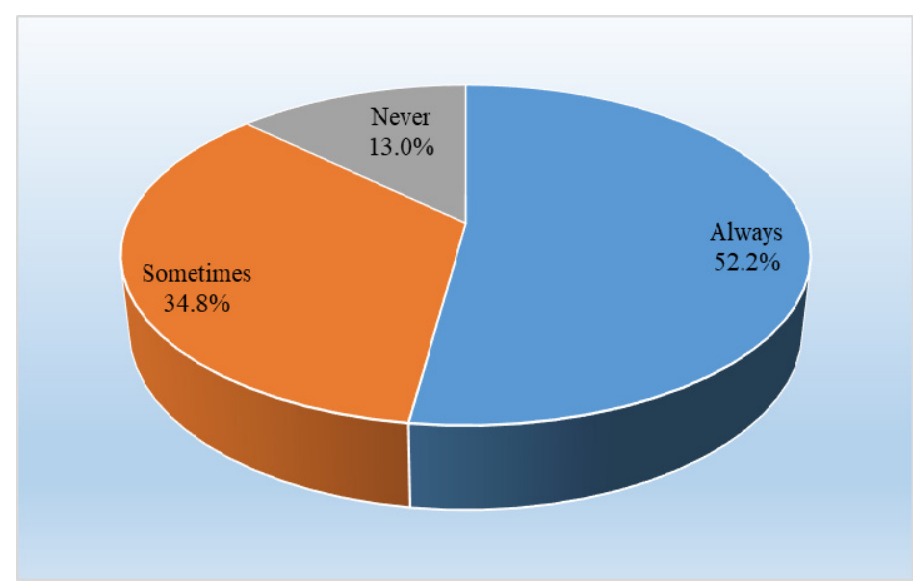

Figure 6. Frequency distribution of question 3

Table 7. Frequency distribution of the answers to the statement question 4. I use dictation as a technique for teaching pronunciation

\begin{tabular}{lcc}
\hline \multicolumn{1}{c}{ Answer } & Frequency & Percent \\
\hline Always & 23 & $50.0 \%$ \\
Sometimes & 11 & $23.9 \%$ \\
Never & 12 & $26.1 \%$ \\
Total & 46 & $100.0 \%$
\end{tabular}

Table 7. describes that 23(50.0\%) of the respondents "always" (use dictation as a technique for teaching pronunciation), 11(23.9\%) sometimes do that, while 12(26.1\%) of the respondents "never" (use dictation as a technique for teaching pronunciation). The bar chart below illustrates these percentages.

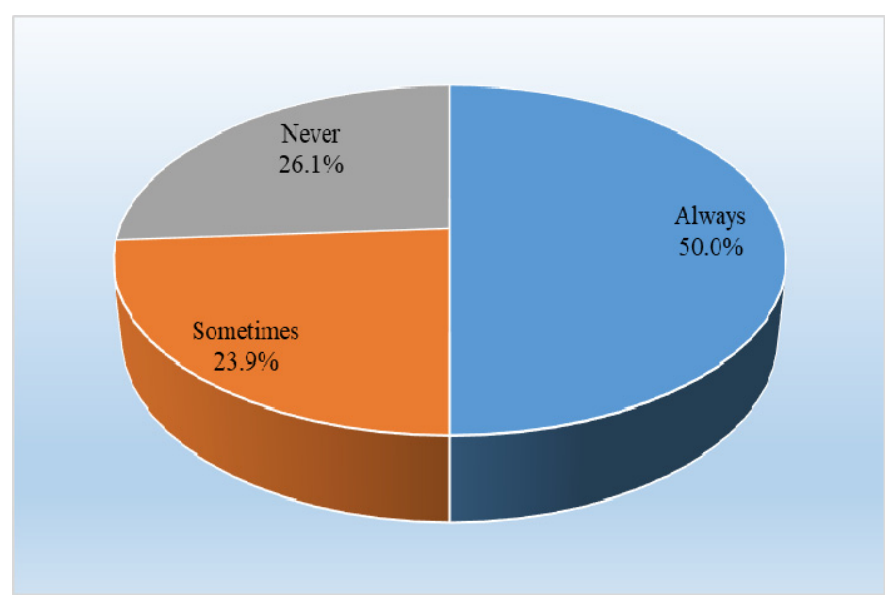

Figure 7. Frequency distribution of question 4. I use dictation as a technique for teaching pronunciation

Table 8. Frequency distribution of the answers to the statement question 5. I use reading aloud and dialogues as techniques for teaching pronunciation

\begin{tabular}{lcc}
\hline \multicolumn{1}{c}{ Answer } & Frequency & Percent \\
\hline Always & 36 & $78.3 \%$ \\
Sometimes & 10 & $21.7 \%$ \\
Total & 46 & \multicolumn{2}{c}{$100.0 \%$} \\
\hline
\end{tabular}

Table 8. demonstrates that the most of ELI instructors 36(78.3\%) "always" (use reading aloud and dialogues as techniques for teaching pronunciation), and the rest 10(21.7\%) "sometimes" do that. The bar chart below illustrates these percentages. 


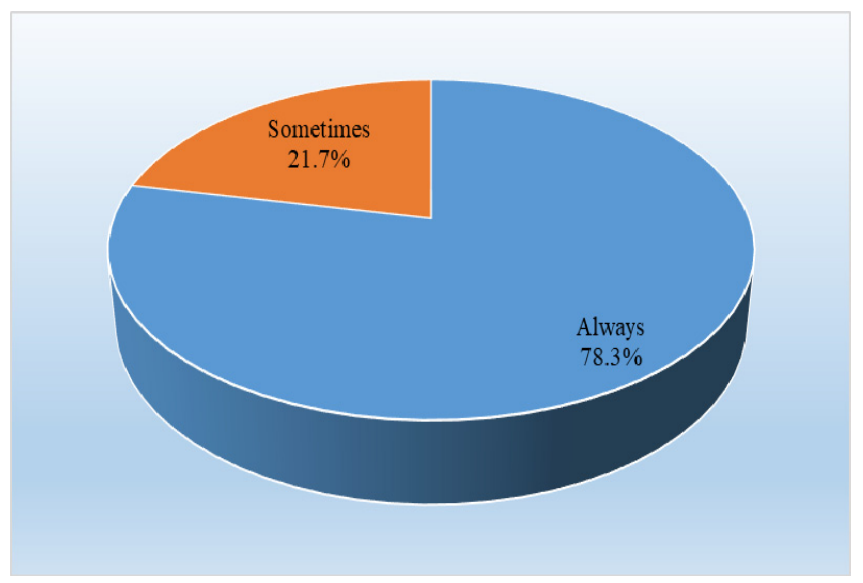

Figure 8. Frequency distribution of question 5. I use reading aloud and dialogues as techniques for teaching pronunciation

Table 9. Frequency distribution of the answers to the statement question 6. I use minimal pairs as a technique for teaching pronunciation

\begin{tabular}{|c|c|c|}
\hline Answer & Frequency & Percent \\
\hline Always & 22 & $47.8 \%$ \\
\hline Sometimes & 16 & $34.8 \%$ \\
\hline Never & 8 & $17.4 \%$ \\
\hline Total & 46 & $100.0 \%$ \\
\hline
\end{tabular}

Table 9. shows that 22(47.8\%) of the respondents "always" (use minimal pairs as a technique for teaching pronunciation), $16(34.8 \%)$ use this sometimes, while $8(17.4 \%)$ "never" (use minimal pairs as a technique for teaching pronunciation). The bar chart below illustrates these percentages.

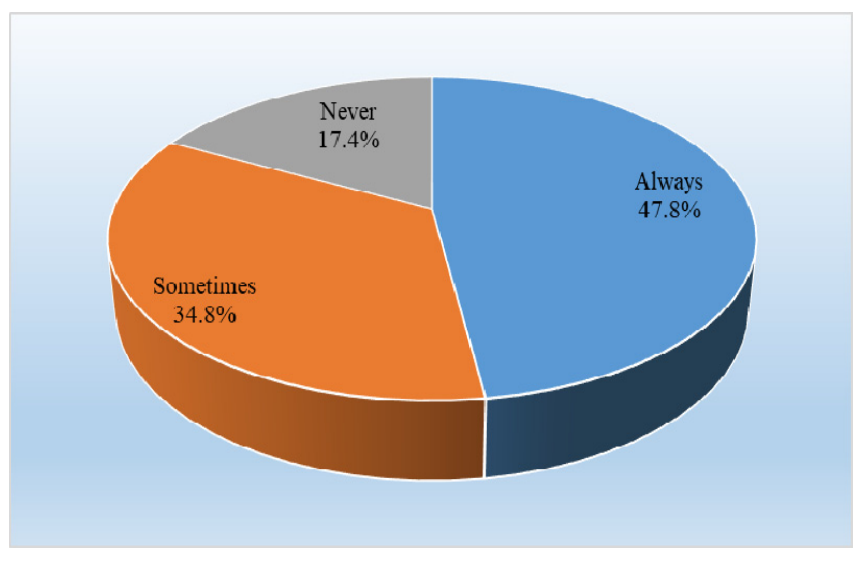

Figure 9. Frequency distribution of question 6. I use minimal pairs as a technique for teaching pronunciation Table 10. Frequency distribution of the answers to the statement question 7. I use transcription as a technique for teaching pronunciation):

\begin{tabular}{lcc}
\hline \multicolumn{1}{c}{ Answer } & Frequency & Percent \\
\hline Always & 21 & $45.7 \%$ \\
Sometimes & 7 & $15.2 \%$ \\
Never & 18 & $39.1 \%$ \\
Total & 46 & $100.0 \%$
\end{tabular}

Table 10. shows that $21(45.7 \%)$ of the respondents "always" (use transcription as a technique for teaching pronunciation), and 7(15.2\%) use it sometimes, while 18(39.1\%) of the respondents "never" (use transcription as a technique for teaching pronunciation). The bar chart below shows these percentages. 


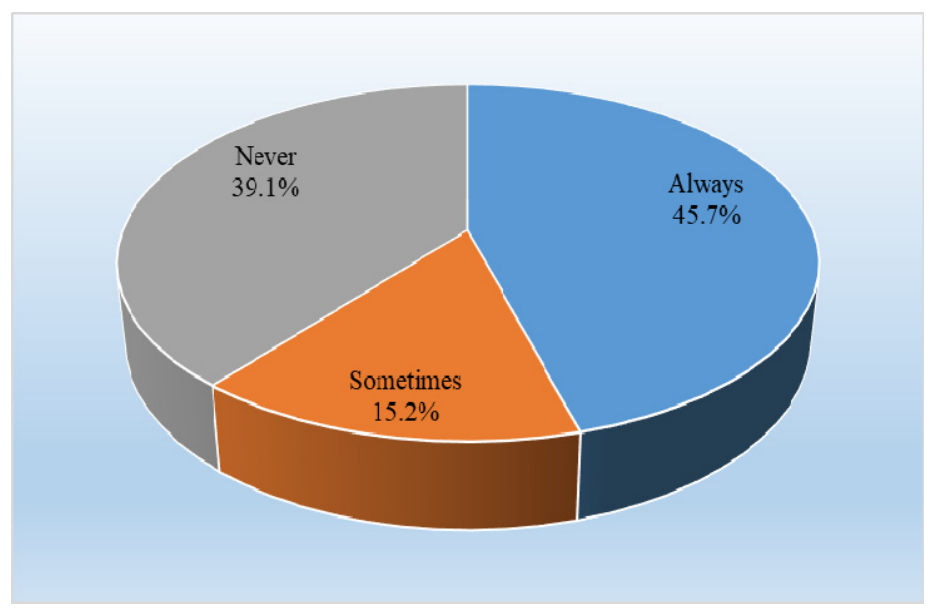

Figure 10. Frequency distribution of question 7. I use transcription as a technique for teaching pronunciation

Table 11. Frequency distribution of the answers to the statement question 8. I use instructional technology in the teaching pronunciation

\begin{tabular}{|c|c|c|}
\hline Answer & Frequency & Percent \\
\hline Always & 29 & $63.0 \%$ \\
\hline Sometimes & 15 & $32.6 \%$ \\
\hline Never & 2 & $4.3 \%$ \\
\hline Total & 46 & $100.0 \%$ \\
\hline
\end{tabular}

Table 11. illustrates that approximately 29(63.0\%) of ELI instructors "always" (use instructional technology in the teaching pronunciation), $15(32.6 \%)$ use it "sometime", while the rest only $2(4.3 \%)$ "never" (use instructional technology in the teaching pronunciation). The bar chart below illustrates these percentages.

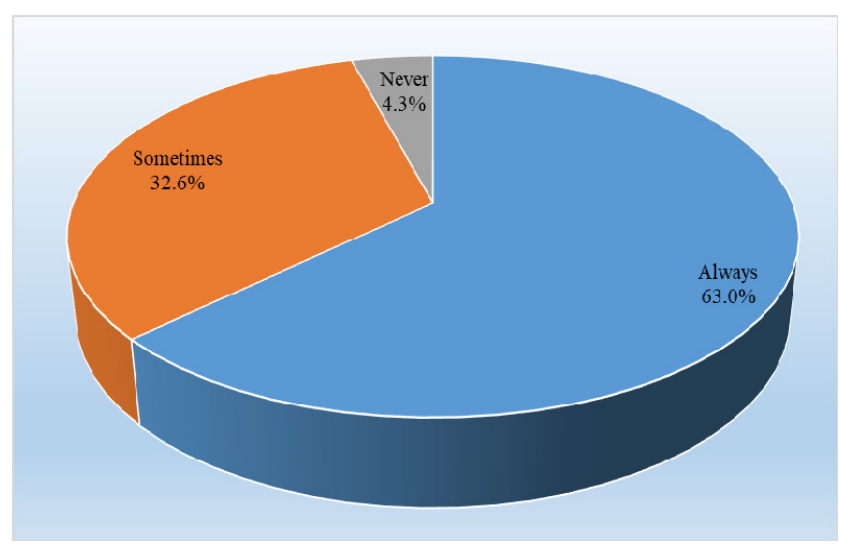

Figure 11. Frequency distribution of question 8. I use instructional technology in the teaching pronunciation

Table 12. Frequency distribution of the answers to the statement question 9. I correct the students' mispronunciation of words in class

\begin{tabular}{|c|c|c|}
\hline Answer & Frequency & Percent \\
\hline Always & 34 & $73.9 \%$ \\
\hline Sometimes & 12 & $26.1 \%$ \\
\hline Total & 46 & $100.0 \%$ \\
\hline
\end{tabular}

Table 12. demonstrates that the most of ELI instructors "always" (correct the students' mispronunciation of words in class), and $12(26.1 \%)$ of the respondents "sometime" (correct the students' mispronunciation of words in class). The bar chart below illustrates these percentages. 


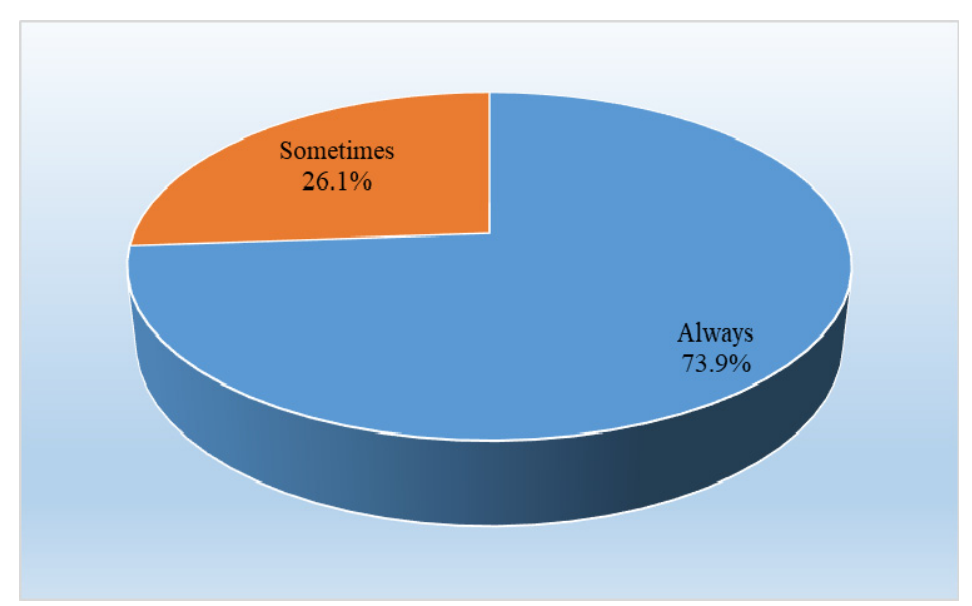

Figure 12. Frequency distribution of question 9. I correct the students' mispronunciation of words in class

Table 13. Frequency distribution of the answers to the statement question 10. I show the learners the differences between English and their native language in terms of pronunciation

\begin{tabular}{lcc}
\hline \multicolumn{1}{c}{ Answer } & Frequency & Percent \\
\hline Always & 27 & $58.7 \%$ \\
Sometimes & 19 & $41.3 \%$ \\
Total & 46 & $100.0 \%$ \\
\hline
\end{tabular}

Table 13. describes that more than half 27(58.7\%) of ELI instructors "always" (show the learners the differences between English and their native language in terms of pronunciation.), and 19(41.3\%) "sometime" (show the learners the differences between English and their native language in terms of pronunciation.). The bar chart below shows these percentages.

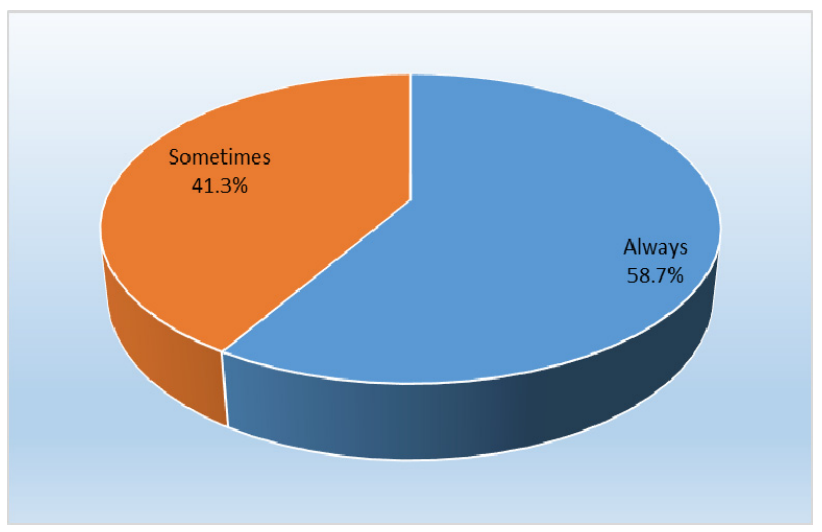

Figure 13.Frequency distribution of question 10. I show the learners the differences between English and their native language in terms of pronunciation 
Table 14. Chi-square test for statement

\begin{tabular}{|c|c|c|c|c|c|c|c|}
\hline No & Items & Mean & Std. & $\begin{array}{l}\text { Chi-Squar } \\
\text { e }\end{array}$ & $\mathrm{p}$-value & median & Interpretation \\
\hline 5 & $\begin{array}{l}\text { I use reading aloud and dialogues } \\
\text { as techniques for teaching } \\
\text { pronunciation. }\end{array}$ & 1.78 & 0.42 & 14.70 & 0.000 & 2.00 & Always \\
\hline 9 & $\begin{array}{l}\text { I correct the students' } \\
\text { mispronunciation of words in } \\
\text { class. }\end{array}$ & 1.74 & 0.44 & 10.52 & 0.001 & 2.00 & Always \\
\hline 8 & $\begin{array}{l}\text { I use instructional technology in } \\
\text { the teaching pronunciation. }\end{array}$ & 1.59 & 0.58 & 23.78 & 0.000 & 2.00 & Always \\
\hline 10 & $\begin{array}{l}\text { I show the students the differences } \\
\text { between English and their native } \\
\text { language in terms of } \\
\text { pronunciation. }\end{array}$ & 1.59 & 0.50 & 1.39 & 0.238 & 2.00 & Always \\
\hline 3 & $\begin{array}{l}\text { I make use of dictionaries as a } \\
\text { technique for teaching } \\
\text { pronunciation. }\end{array}$ & 1.39 & 0.71 & 10.61 & 0.005 & 2.00 & Always \\
\hline 2 & $\begin{array}{l}\text { I have special training on teaching } \\
\text { pronunciation. }\end{array}$ & 1.33 & 0.70 & 8.65 & 0.013 & 1.00 & Sometimes \\
\hline 6 & $\begin{array}{l}\text { I use minimal pairs as a technique } \\
\text { for teaching pronunciation. }\end{array}$ & 1.30 & 0.76 & 6.44 & 0.040 & 1.00 & Sometimes \\
\hline 4 & $\begin{array}{l}\text { I use dictation as a technique for } \\
\text { teaching pronunciation. }\end{array}$ & 1.24 & 0.85 & 5.78 & 0.056 & 1.00 & Sometimes \\
\hline 7 & $\begin{array}{l}\text { I use transcription as a technique } \\
\text { for teaching pronunciation. }\end{array}$ & 1.07 & 0.93 & 7.09 & 0.029 & 1.00 & Sometimes \\
\hline 1 & $\begin{array}{l}\text { I studied several courses in } \\
\text { teaching pronunciation }\end{array}$ & 1.04 & 0.84 & 0.30 & 0.859 & 1.00 & Sometimes \\
\hline
\end{tabular}

Table 14. displays the means and standard deviations, and the results of chi-square test for each statement as well to median and its interpretation. In general, we reveal that many chi-square values are statistically notable (p-values are less than 0.05), namely, significant difference exists among the observed frequencies, and straightforwardly, significant difference appears among ELI instructors in their point of view toward these statements. According to the "mean", the statements had been ordered in descending mean order from the highest to the lowest, so, we find the following:

1- The statement (question 5. I use reading aloud and dialogues as techniques for teaching pronunciation) has chi-square (14.70) and p-value (0.000) which is significant, i.e statistically significant difference exists among ELI instructors in their point of view toward the statement - for favor of (Always).

2- The statement (question 9. I correct the students' mispronunciation of words in class) has chi-square (10.52) and p-value (0.001) which is significant, i.e. statistically significant difference arises among ELI instructors in their point of view toward the statement - for favor of (Always).

3- The statement (question 8. I use instructional technology in the teaching pronunciation) has chi-square (23.78) and p-value (0.000) which is significant, i.e. statistically significant difference appears among ELI instructors in their point of view toward the statement - for favor of (Always).

4- The statement (question 10. I show the learners the differences between English and their native language in terms of pronunciation.) has chi-square (1.39) and p-value (0.238) which is non-significant, i.e. statistically non-significant difference among ELI instructors in their point of view toward the statement.

5- The statement (q3. I make use of dictionaries as a technique for teaching pronunciation) has chi-square (10.61) and p-value (0.005) which is significant, i.e. statistically significant difference emerges among ELI instructors in their point of view toward the statement - for favor of (Always). 
6- The statement (question 2. I have special training on teaching pronunciation) has chi-square (8.65) and p-value (0.013) which is significant, i.e. statistically significant difference arises among ELI instructors in their point of view toward the statement - for favor of (Sometimes).

7- The statement (question 6. I use minimal pairs as a technique for teaching pronunciation) has chi-square (6.44) and p-value (0.040) which is significant, i.e. statistically significant difference exists among ELI instructors in their point of view toward the statement - for favor of (Sometimes).

8- The statement (question 4. I use dictation as a technique for teaching pronunciation) has chi-square (5.78) and p-value (0.056) which is non-significant, i.e. statistically non-significant difference among ELI instructors in their point of view toward the statement.

9- The statement (question 7. I use transcription as a technique for teaching pronunciation) has chi-square (7.09) and p-value (0.029) which is significant, i.e. statistically significant difference appears among ELI instructors in their point of view toward the statement - for favor of (Sometimes).

10- The statement (question 1. I studied several courses in teaching pronunciation) has chi-square $(0.30)$ and p-value $(0.859)$ which is non-significant, i.e. statistically insignificant difference among ELI instructors in their point of view toward the statement.

\section{Conclusion}

The findings of this study have emphasized the status of pronunciation teaching at ELI. The three areas the researcher focused on in this study were instructors' beliefs, instructors' practices, and instructors' training. It is evident from the study that a high level of agreement expressed the importance of teaching pronunciation. A maximum of the surveyed instructors recognized that the objective of pronunciation teaching is to support students to pronounce words correctly. They, therefore, believed that pronunciation should be taught communicatively, indicating the ineffectiveness of explicit pronunciation teaching. Although the instructors found teaching pronunciation difficult, they felt relatively confident in the methods they used to teach pronunciation at both levels. These methods included both segmental and suprasegmental approaches.

As for their teaching practices, the results showed that the instructors preferred using usual classroom techniques such as repetition, speaking aloud, or correcting mispronounced words largely to teach pronunciation to learners. However, they were disinclined to employ contemporary techniques such as computer or language labs. The instructors were dissatisfied with materials available to them to teach pronunciation. They relied only on the activities that were suggested in the general textbooks. They were also dissatisfied with the training they had received for teaching pronunciation. They stated that an aspiration for supplementary professional training courses to acclimatize them with a variety of pedagogical methods. Thus, it is expected that more professional training opportunities will become available to help instructors incorporate pronunciation into their teaching.

\section{Recommendation}

The results of the current study show a clear need for further professional development and training in the area of teaching pronunciation for EFL instructors. Also instructors should be encouraged to integrate pronunciation in their teaching at both levels, segmental and suprasegmental more effectively. Introducing more materials and technological resources may help to fill the current teaching gap, which is mainly a result of traditional strategies and a focus on pronunciation tasks found in general English language textbooks. Hence, the instructors should be motivated to be open to use technology to allow learners to interact, or other supplemental materials that support teaching pronunciation.

Although the current study can give a glimpse of the current practices and beliefs regarding the teaching of pronunciation in English language institutes in Saudi Arabia, it is limited to the ELI at King Abdulaziz University, and therefore, it is hard to generalize the results to other English language institutes in the Kingdom. Future research needs to explore the beliefs and practices of pronunciation teaching in all English language institutes and centers in Saudi Arabia. Another limitation is relevant to the tool used in the current study. Because the use of a survey is not enough to capture the full range of practices by the instructors, other studies that use observations and interviews are needed for a more thorough investigation.

\section{Acknowledgement}

The Deanship of Scientific Research (DSR), King Abdulaziz Uiversity, Jeddah, funded this project, under grant No. (DF-515-306-1441). The author, therefore, gratefully acknowledge DSR technical and financial support. 


\section{References}

Ahmad, J., \& Muhiburrahman, M. (2013). Instructors' perspectives on errors in English consonant sounds by Saudi EFL learners. Asian Journal of Humanities and Social Sciences, 1(3), 150-163.

Ahmad. J. (2011). Pronunciation problems among Saudi learners: A case study at the preparatory year program, Najran University Saudi Arabia. Language in India. 11, 22-36.

Al Mafalees, F. (2020), Mispronunciation of English Consonant Sounds by Yemeni EFLL earners at Secondary Schools: An Analysis of the Problems and Some Remedies. Language in India, 20(1), January 2020: ISSN 1930-2940.

Bintuki, T. A. (2008). Analysis of pronunciation errors of Saudi ESL learners. (MA thesis published). Southern Illinois University.

Borg, S. (2003). Teacher cognition in language teaching: A review of research on what language teachers think, know, believe, and do. Language Teaching, 36(2), 81-109. https://doi.org/10.1017/S0261444803001903

Burns, A. (2006). Integrating research and professional development on pronunciation teaching in a national adult ESL program. TESL Reprter, 39(2), 34-41.

Cerezo, R., Calderónb, V. \& Romero, C. (2019). A holographic Mobile-based Application for Practicing pronunciation of Basic English Vocabulary for Spanish Speaking Children. International Journal of Human-Computer Studies, 124, 13-2. https://doi.org/10.1016/j.ijhcs.2018.11.009

Couper, G. (2006). The short and long-term effects of pronunciation instruction. Prospect, 21(1), 46-66.

Derwing, T. M., \& Munro, M. J. (2005). Second language accent and pronunciation teaching: A research-based approach. TESOL Quarterly, 39(3), 379-397. https://doi.org/10.2307/3588486

Derwing, T. M., Munro, M. J., \& Wiebe, G. (1998). Evidence in favor of a broad framework for pronunciation instruction. Language Learning, 48(3), 393-410. https://doi.org/10.1111/0023-8333.00047

Elliot, A. R. (1995). Foreign language phonology: Field independence, attitude, and the success of formal instruction in Spanish pronunciation. The Modern Language Journal, 79(iv), 530-542. https://doi.org/10.1111/j.1540-4781.1995.tb05456.x

Foote, J. A., Holtby, A. K., \& Derwing, T. M. (2011). Survey of the teaching of pronunciation in adults ESL programs in Canada, 2010. TESL Canada Journal, 29(1), 1-22. https://doi.org/10.18806/tesl.v29i1.1086

Foote, J., Trofimovich, P., Collins, L., \& Urzúa, F. (2016). Pronunciation teaching practices in communicative second language classes. The Language Learning Journal, 44(2), 181-196. https://doi.org/10.1080/09571736.2013.784345

Ghorbani, M. R., Neissari, M., \& Kargozari, H. R. (2016). The effect of explicit pronunciation instruction on undergraduate English as a foreign language learners'vowel perception. Language and Literacy, 18(1), 57-70. https://doi.org/10.20360/G2XW2K

Gilakjani, A. (2012). A Study of factors affecting EFL learners' English pronunciation learning and the strategies for instruction. International Journal of Humanities and Social Science, 2(3), 119-128.

Goodwin, J. (2001). Teaching pronunciation. In: Celce-Murcia, M. (Ed.). Teaching English as Second or Foreign Language. Australia: Heinle \& Heinle.

Hago, O., \& Khan, W. (2015). The pronunciation problems faced by Saudi EFL learners at secondary schools. Education and Linguistics Research, 1(2), 85-99. https://doi.org/10.5296/elr.v1i2.7783

Hameed, P. F., \& Aslam, M. S. (2015). Pronunciation as a stumbling Block for the Saudi English learners: An analysis of the problems and some remedies. Theory and practice in language studies, 5(8), 1578-1585. https://doi.org/10.17507/tpls.0508.06

Hismanoglu, M. \& Hismanoglu, S. (2010). Language teachers' preferences of pronunciation teaching techniques: traditional or modern? Procedia Social and Behavioral Sciences, 2 (2), 983-989. https://doi.org/10.1016/j.sbspro.2010.03.138

Jones, R. H. (1997). Beyond "listen and repeat": Pronunciation teaching materials and theories of second language acquisition. System, 25(1), 103-112. https://doi.org/10.1016/S0346-251X(96)00064-4

MacDonald, S. (2002). Pronunciation: Views and practices of reluctant teachers. Prospect, 17(3), 3-18. 
Morley, J. (1991). The pronunciation component in teaching English to speakers of other languages. TESOL Quarterly, 25(3), 481-520. https://doi.org/10.2307/3586981

Pennington, M. C., \& Richards, J. C. (1986). Instructors of English to speakers of other languages. TESOL Quarterly, 20(2), 207-225. https://doi.org/10.2307/3586541

Rossiter, M. (2003). The effects of pronunciation instruction on the accuracy, fluency, and complexity of L2 accented speech. Applied Language Learning, 13(1), 1-17.

Saito, K. (2007). The influence of explicit phonetic instruction on pronunciation teaching in EFL settings: The case of English vowels and Japanese learners of English. The Linguistics Journal, 3(3), 16-40.

Saito, K. (2011). Examining the role of explicit phonetic instruction in native-like and comprehensible pronunciation development: An instructed SLA approach to L2 phonology. Language Awareness, 20(1), 45-59. https://doi.org/10.1080/09658416.2010.540326

Saito, K. (2012). Effects of instruction on L2 pronunciation development: A synthesis of 15 quasi-experimental intervention studies. TESOL Quarterly, 46(4), 842-854. https://doi.org/10.1002/tesq.67

Saito, K., \& Lyster, R. (2012). Effects of form-focused instruction and corrective feedback on L2 pronunciation development of $/ \mathrm{x} /$ by Japanese learners of English. Language Learning, 62(2). https://doi.org/10.1111/j.1467-9922.2011.00639.x

Setter, J., \& Jenkins, J. (2005). Pronunciation. State-of-the-Art Review Article, 38, 1-17. https://doi.org/10.1017/S026144480500251X

Skorvagova, E., Tirpakova A., Markechova, D. \& Kralovaa, Z. (2017). Reducing student teachers' foreign language pronunciation anxiety through psycho-social training. System, 65, 49-60. htps://doi.org/10.1016/j.system.2017.01.001

Tergujeff, E. (2012a). English pronunciation teaching: Four case studies from Finland. Journal of Language Teaching and Research, 3(4), 599-607. https://doi.org/10.4304/jltr.3.4.599-607

Zoghbor, W. (2018). Teaching English pronunciation to multi-dialect first language learners: The revival of the Lingua Franca Core (LFC). System, 78, 1-14. https://doi.org/10.1016/j.system.2018.06.008

\section{Copyrights}

Copyright for this article is retained by the author(s), with first publication rights granted to the journal.

This is an open-access article distributed under the terms and conditions of the Creative Commons Attribution license (http://creativecommons.org/licenses/by/4.0/). 